\title{
Steroid Metabolism and Effects in Central and Peripheral Glial Cells
}

\author{
Roberto C. Melcangi, Valerio Magnaghi, Luciano Martini \\ Department of Endocrinology, University of Milan, Via Balzaretti 9, Milan 20133, Italy
}

Received 1 February 1999; accepted 4 May 1999

\begin{abstract}
Hormonal steroids participate in the control of a large number of functions of the central nervous system (CNS); recent data show that they may also intervene at the level of the peripheral nervous system (PNS). Both the CNS and the PNS metabolize endogenous as well as exogenous steroids; one of the major enzymatic system is represented by the $5 \alpha$-reductase-3 $\alpha$-hydroxysteroid complex. This is a versatile system, since every steroid possessing the delta 4-3keto configuration (e.g., testosterone, progesterone, deoxycorticosterone) may be a substrate. High levels of $5 \alpha$ reductase are found in the white matter of the CNS and in purified myelin. The observation that, in addition to neurons, glia may be a target for steroid action is an important recent finding. The effects of progesterone, testosterone, corticoids, and their respective $5 \alpha$ and $3 \alpha-5 \alpha$ derivatives on the expression of glial genes are presented and discussed. It has also been found that progesterone and/or its $5 \alpha$-reduced metabolites increase
\end{abstract}

\section{INTRODUCTION}

Hormonal steroids participate in the control of a large number of brain functions during the fetal and neonatal period, when they act to organize the nervous system, as well as during adulthood, when they act to regulate several physiological functions. Hormonal steroids may also intervene in the process of aging in the central nervous system (CNS), especially in some

\footnotetext{
Correspondence to: R. C. Melcangi

Contract grant sponsor: CNR; contract grant numbers: 95.01020.PF40, 95.00868.PF41 E.765

Contract grant sponsor: Telethon Italy; contract grant number:

(C) 1999 John Wiley \& Sons, Inc. CCC 0022-3034/99/040471-13
}

the mRNA for the two major proteins of peripheral myelin, the glycoprotein Po and the peripheral myelin protein 22, in the sciatic nerve of normal and aged animals and in Schwann cells. The hypothesis has been put forward that glycoprotein Po might be under the control of progestagens acting mainly via the progesterone receptor, and that peripheral myelin protein 22 might be controlled via an interaction of steroids with the $\gamma$-aminobutyric acid (GABA)ergic system. It is known that tetrahydroprogesterone, the $3 \alpha-5 \alpha$-reduced metabolite of progesterone, interacts with the $\mathbf{G A B A}_{\mathrm{A}}$ receptor. Our recent data show that several subunits of this receptor are present in sciatic nerve as well as in Schwann cells that reside in this nerve. These data open multiple possibilities for new therapeutic approaches to demyelinating diseases. ๑ 1999 John Wiley \& Sons, Inc. J Neurobiol 40: 471-483, 1999

Keywords: glia; progesterone; myelin; metabolism; testosterone specific structures (e.g., the hippocampus). Classical intracellular receptors for each family of hormonal steroids are present in many CNS structures. Some families of receptors are preponderant in some particular brain areas. For instance, glucocorticoid receptors (GR) and minerocorticosteroid receptors (MR) prevail in the limbic system, while the receptors for sex hormones [androgen receptors (AR), estrogen receptors $(\mathrm{ER} \alpha$ and $\beta)$, and progesterone receptors $(\mathrm{PR})]$ have a more generalized distribution, although higher concentrations are seen in the hypothalamus and amygdala (McEwen, 1991, 1994). It is important to note that the presence of receptors for hormonal steroids is not limited to neurons, but that these are also found in glial elements (e.g., astrocytes and oligodendrocytes) (Vielkind et al., 1990; Jung-Testas et al., 
1992, 1994; Langub and Watson, 1992; Wolff et al., 1992). Steroid receptors in both neurons and glia undoubtedly have important physiological implications because of the close cross-talk existing between neurons and glial cells (see below). One important observation is that the brain may metabolize endogenous and exogenous steroids. Several enzymatic systems have been described, and some of them have been fully characterized (for review, see Celotti et al., 1992; Martini, 1982). Among these, some have the peculiarity of totally changing the endocrine profile of a given steroid [e.g., aromatization of testosterone (T) to estradiol (E)], while others have the property of enhancing its activity [e.g., $5 \alpha$-reductase $(5 \alpha-\mathrm{R})$ which converts $\mathrm{T}$ to dihydrotestosterone (DHT)]; moreover, some enzymes (e.g., $3 \alpha$-hydroxysteroid dehydrogenase, $3 \alpha$-HSD) modify steroids so that their metabolites may interact with receptors other than the classical steroid receptors. As detailed below, the enzymes $5 \alpha$-R and $3 \alpha$-HSD are present in neurons and glia (Melcangi et al., 1990a, 1993, 1994a).

More recent evidence also indicates that the peripheral nervous system (PNS), and particularly the Schwann cells (which are the equivalent in the periphery to the glia elements present in the CNS), which may be sensitive to steroid effects, possess steroid receptors (Jung-Testas et al., 1996; Melcangi et al., 1998a; Magnaghi et al., 1999) and the enzymes for steroid metabolism (Melcangi et al., 1990b, 1992). Some data suggest that the PNS and Schwann cells may also be the site of synthesis for some hormonal steroids (Koenig et al., 1995). The enzymatic complex formed by $5 \alpha$-R and $3 \alpha$-HSD in the CNS (for review, see Celotti et al., 1992; Martini, 1982) is very versatile in the sense that every steroid possessing the delta 4-3keto configuration may be first $5 \alpha$-reduced and subsequently $3 \alpha$-hydroxylated. For instance, $\mathrm{T}$ can be converted into DHT and subsequently into $5 \alpha$-androstane- $3 \alpha, 17 \beta$-diol ( $3 \alpha$-diol); progesterone (P) can be metabolized into dihydroprogesterone (DHP) and subsequently into $3 \alpha, 5 \alpha$-tetrahydroprogesterone (THP); corticosterone into dihydrocorticosterone (DHC); and finally, deoxycorticosterone (DOC) into $5 \alpha$-dihydrodeoxycorticosterone (DHDOC) and $3 \alpha, 5 \alpha$-tetrahydrodeoxycorticosterone (THDOC). As detailed below, some $5 \alpha$-reduced- $3 \alpha$-hydroxysteroids may exert important biological activities with a mechanism different from that of the parent steroids.

The existence of more than one $5 \alpha-\mathrm{R}$ isozyme had been postulated years ago on the basis of studies using various inhibitors (Motta et al., 1986; Zoppi et al., 1992) and different substrates (Motta et al., 1986). More recently, two isoforms of the $5 \alpha$-R (types 1 and 2) have been cloned (Andersson et al., 1989, 1991;
Labrie et al., 1992; Normington and Russell, 1992; Russell and Wilson, 1994; Levy et al., 1995). In men, the type $15 \alpha$-R gene, on chromosome 5 , is composed of five exons and four introns and produces a protein of 259 amino acids. The type $25 \alpha$-R gene, located on chromosome 2 , has a similar structure, but the resulting protein is composed of 254 amino acids. The structures of the enzymatic proteins, determined from their respective cDNAs, show a limited degree of homology (about 47\%), and a predicted molecular weight of $28-29 \mathrm{kD}$. In terms of primary structures, both isozymes are composed of a high number of hydrophobic amino acid residues distributed throughout the molecule, causing the enzymes to be located in intracellular membranes. Although the two isoforms of the $5 \alpha$-R (types 1 and 2) catalyze the same reaction (e.g., T to DHT, P to DHP), they possess different biochemical and possibly functional properties. The affinity of $\mathrm{T}$ for the type 1 isoform is about 15 - to 20 -fold lower than that for the type 2 isoform. The two isoforms have a different $\mathrm{pH}$ optimum: the type 1 isoform is active in a wide range of $\mathrm{pH}$ (from 5 to 8), while the type $25 \alpha$-R possesses a narrow $\mathrm{pH}$ optimum around 5 , with a very low activity at $\mathrm{pH} 7.5$. The two isozymes also show a differential sensitivity to synthetic inhibitors such as finasteride, which preferentially blocks the human type 2 isozyme (Thigpen and Russell, 1992). High levels of $5 \alpha-\mathrm{R}$ are observed in CNS areas particularly rich in white matter, such as the midbrain (Snipes and Shore, 1982), the pons (Krieger et al. 1983), the spinal cord (MacLusky et al., 1987), the corpus callosum, the anterior commissure, and the optic chiasm (Melcangi et al., 1988a, 1989). Also, the formation of $3 \alpha$-diol is significantly higher in white-matter structures than in the gray matter (Melcangi et al. 1988a, 1988b). The $5 \alpha$-R, but not the $3 \alpha-\mathrm{HSD}$, is present in elevated concentrations in purified myelin preparations obtained from the rat brain (Melcangi et al. 1988a,b, 1989). The physiological meaning of this localization of $5 \alpha-\mathrm{R}$ is still obscure, but the hypothesis that $5 \alpha$-reduced steroids locally formed in myelin might play a role in the process of myelination is certainly attractive. Such an hypothesis is indirectly supported by data showing that there is a peak of $5 \alpha-\mathrm{R}$ activity in rat CNS (Massa et al., 1975; Degtiar et al., 1981) and in the purified CNS myelin in the first weeks of life (Melcangi et al., 1988b), the time when myelinization is initiated (Norton and Poduslo, 1973). Moreover, the cells which manufacture myelin, the oligodendrocytes, possess some $5 \alpha-\mathrm{R}$ activity (Melcangi et al., 1988b, 1993, 1994a).

Data on the distribution of the $5 \alpha$-R in different cell types in the rat brain show that neurons possess significantly higher amounts of $5 \alpha-\mathrm{R}$ activity than 
oligodendrocytes and astrocytes (Melcangi et al., 1993, 1994a). In cultures of rat brain cells, two distinct populations of astrocytes may be distinguished on morphological and antigenic bases, the so-called type 1 and type 2 astrocytes. Type 1 astrocytes show a fibroblast-like aspect and are positive for the presence of the glial fibrillary acidic protein (GFAP) and negative to an antibody (A2B5) direct against the membrane gangliosides GD1 $\beta$, GT1, and GQ. Type 2 astrocytes have a process-bearing morphology, resembling that of neurons or oligodendrocytes, and are positive for both GFAP and the A2B5 antibody. Among these glial cells, the type 2 astrocytes possess considerable $5 \alpha-\mathrm{R}$ activity, while type 1 astrocytes (A1) are almost devoid of such activity. Surprisingly, the enzyme $3 \alpha$-HSD appears to be mainly localized in A1 (Melcangi et al., 1993, 1994a), with very low levels in other glial elements and in neurons. These data suggest that neurons and glial cells can both participate in the $5 \alpha$-reductive metabolism of T and other delta 4-3 keto steroids. It must be pointed out that neurons are the only cell population which, in addition to the $5 \alpha-\mathrm{R}$, also contain the enzyme aromatase and consequently are able to transform androgens into estrogens (Negri-Cesi et al., 1992). Interestingly, very recently Garcia-Segura et al. (1999) observed that aromatase is expressed also in astrocytes after brain injury. As previously mentioned, $3 \alpha$-HSD may be considered the second element of the $5 \alpha-\mathrm{R}$ system. The formation of $3 \alpha$-hydroxylated $5 \alpha-$ reduced derivatives may subserve different physiological roles; this reaction may be of importance (a) for decreasing the amounts of intracellular $5 \alpha$-reduced compounds available for binding to the corresponding intracellular steroid receptors, or (b) for producing steroid derivatives which may act through nongenomic mechanisms (e.g., via the $\mathrm{GABA}_{\mathrm{A}}$ receptor; see below).

\section{EFFECT OF HORMONAL STEROIDS ON GLIAL CELLS OF THE CNS}

\section{Progesterone and Androgens}

The cytoskeletal protein GFAP, a component of the intermediate glial filaments, is considered an important and specific astrocytic marker, since it is found only in astrocytes and radial glia. This protein is involved in modulating astrocyte shape and motility (Laping et al., 1994). Recent data have shown that GFAP may be under the control of a wide variety of humoral principles which include cytokines, growth factors, and hormonal steroids (Laping et al., 1994; for review, see Garcia-Segura et al., 1996). In this context, it has been shown that in vivo treatment with corticosterone and other corticoids (e.g., dexamethasone) inhibits GFAP expression in the neonatal and adult rat brain (Laping et al., 1991; Nichols et al., 1990a,b; Tsuneishi et al., 1991). In contrast, corticosterone increases GFAP expression in cultured astrocytes (Rozovsky et al., 1995); this result suggests that the effects observed in vivo are indirect and possibly mediated via nearby neurons or other glial elements (Rozovsky et al., 1995). With regard to sex steroids, castration of male rats increases the levels of GFAP mRNA and protein in the hippocampus (Day et al., 1990, 1993). It is interesting that among the gonadal steroids tested (estradiol, T, and DHT), only estradiol proved able to counteract the effect of castration (Day et al., 1993). At variance with what happens in the hippocampus, castration decreases GFAP immunoreactivity in the hypothalamus, a phenomenon that seems to be counteracted by T and DHT, but not by estradiol (Day et al., 1993). Interesting relationships between androgens and astrocytic function also emerge from the observations that hypothalamic astrocytes exhibit an increased in GFAP immunoreactivity in androgen-insensitive testicular feminized mice (McQueen et al., 1990), and that hypothalamic and hippocampal astrocytes show an increased GFAP immunoreactivity in hypogonadal mice ( $h p g$ ) (McQueen, 1994). Surprisingly, in hpg mice, which possesses normal sex hormone receptors, estrogens and aromatizable androgens, but not DHT, are able to normalize hippocampal GFAP immunoreactivity without altering that of the hypothalamus. After a penetrating brain injury, sex steroids (estradiol and $\mathrm{P}$ in females, and $\mathrm{T}$ in males) are able to decrease gliosis (including astrocytic proliferation), resulting in a decrease in the number of GFAP-positive astrocytes in the lesioned area (Garcia-Estrada et al., 1993). In the arcuate nucleus and the hilus of the dentate gyrus of adult female rats, the surface density of GFAP-immunoreactive cells fluctuates throughout the estrous cycle (Garcia-Segura et al., 1994a,b, 1996), decreases after ovariectomy, and increases after the administration of either estradiol or P (Luquin et al., 1993). Recently, it has also been observed that the levels of GFAP mRNA and immunoreactivity show sex differences in the arcuate nucleus of the rat, with lower levels in females than in males (Chowen et al., 1995). Androgenization of neonatal females increases GFAP mRNA to male levels, while castration of newborn males, without $\mathrm{T}$ substitution, reduces GFAP mRNA to the levels found in females (Chowen et al., 1995). Taken together, these data point to a possible influence of sex steroids on the expression and synthesis of 
GFAP. However, the data collected so far do not address the question of whether sex hormones act directly on the astrocytes to exert these influences.

A systematic study of the effects of sex steroids and their metabolites on the expression of GFAP in astrocytic cultures was recently performed in the authors' laboratory. This study analyzed the effects exerted by $\mathrm{P}$ and $\mathrm{T}$ and by their respective $5 \alpha$-reduced metabolites (DHP and THP, and DHT and $3 \alpha$-diol) on type 1 astrocytes (Melcangi et al., 1996a). The cultures were exposed to the various steroids for 2, 6, and $24 \mathrm{~h}$, and GFAP mRNA was measured by Northern blot analysis. A significant elevation in GFAP mRNA was observed after exposure to either P or DHP; the effect of DHP appeared more promptly $(2 \mathrm{~h})$ than that of $\mathrm{P}(6 \mathrm{~h})$. This result suggests that the effect of $\mathrm{P}$ might be linked to its conversion into DHP; this hypothesis has been confirmed by showing that the addition of finasteride (a blocker of the $5 \alpha-\mathrm{R}$ ) is able to completely abolish the effect of P. At late intervals, exposure to DHP caused a decrease rather than an increase in GFAP gene expression (Melcangi et al., 1996a). This inhibitory effect appears similar to the one evoked by direct exposure to THP; consequently, THP may be the active metabolite exerting an inhibitory effect on GFAP mRNA. This is supported by the observation that type 1 astrocytes are extremely rich in the enzyme $3 \alpha$-HSD, which converts DHP into THP (Melcangi et al., 1994a). Thus, the biphasic effect of DHP (stimulatory at earlier intervals and inhibitory at later times) may be related to the sequential conversion of $\mathrm{P}$ into its related metabolites DHP and THP; because of this differential intracellular signaling pathways are probably involved. $\mathrm{P}$ and DHP may bind to their specific intracellular receptors present in the astrocytes (Jung-Testas et al., 1992). In this context, it is important to recall that P and DHP bind to the intracellular P receptor (Lee et al., 1979; Rupprecht et al., 1993; Schenborn and Karavolas, 1983), while THP does not. Some steroids, and in particular $3 \alpha$-hydroxy- $5 \alpha$-reduced pregnane derivatives, are potent ligands for the $\mathrm{GABA}_{\mathrm{A}}$ receptor in the CNS (Majewska et al., 1986; Paul and Purdy, 1992; Puia et al., 1990). On the basis of these observations, it is possible that the inhibitory effect exerted by THP (and probably by DHP after its conversion into THP) on GFAP expression might be mediated by the activation of $\mathrm{GABA}_{\mathrm{A}}$ receptors.

In the case of androgens, $\mathrm{T}$ and $3 \alpha$-diol did not change GFAP expression at any time of exposure, while DHT produced a significant decrease of GFAP mRNA only after $24 \mathrm{~h}$ (Melcangi et al., 1996a). This study should be completed using synthetic androgenic compounds which do not undergo metabolic conver- sions, but which do bind to and activate the AR, like $\mathrm{T}$ and DHT. All these new findings indicate that sex steroids may act directly on astrocytes.

\section{Glucocorticoids and Minerocorticoids}

Because of their antiinflammatory and antiimmune properties, glucocorticoids are one of the major therapeutic options for the treatment of multiple sclerosis and other demyelinating diseases. However, little and conflicting information is available on the direct effects that corticoids might exert on the oligodendrocytes (i.e., the myelin-producing cells), on other kinds of glial cells, and on myelin components, e.g., the myelin basic protein (MBP), in the CNS (Meyer and Fairman, 1985; Preston and McMorris, 1984; Tsuneishi et al., 1991). Because of this, our laboratory examined the effects of different types of glucocorticoids and minerocorticoids on MBP expression using oligodendrocyte cultures. Moreover, on the basis of the presence of the enzyme $5 \alpha-\mathrm{R}$ and $3 \alpha$-HSD in these cells (Melcangi et al., 1990a, 1993, 1994a) the effect of the $5 \alpha$-reduced metabolites was also examined. Among the different steroids tested (corticosterone, DHC, DOC, DHDOC, and THDOC), only DHDOC was effective in modifying MBP gene expression in cultures of oligodendrocytes; mRNA levels of this typical oligodendrocyte marker were decreased following exposure to this steroid for $24 \mathrm{~h}$ (Melcangi et al., 1997a). To our knowledge, this is the first demonstration that adrenal steroids in their native or $5 \alpha$-reduced forms modify MBP gene expression in oligodendrocyte cultures. The efficacy of steroids on this parameter has so far been shown only from in vivo studies (Tsuneishi et al., 1991). The finding that DHDOC is able to modify MBP gene expression necessitates a few comments. First, it is important to point out that the mode of action of this steroid on MBP mRNA is not yet clear. No studies are available to indicate whether DHDOC binds and activates the GR and/or the MR. The fact that the other steroids tested, which are able to bind to the GR and MR, are inactive would tend to eliminate the possibility of an effect of DHDOC via those receptors. DHDOC has, however, been shown to bind to and activate the PR (Tsuneishi et al., 1991; Rupprecht 1996). Consistent with this is the fact that DHDOC, like progesterone, exerts antiminerocorticoid activity (Sekihara and Yazaki, 1993). It is thus possible that the effects of this steroid on MBP gene expression may be mediated via the PR, a receptor that is present in oligodendrocytes (Jung-Testas et al., 1992, 1994). The physiological meaning of these results is still unclear. However, it is important to recall once more that $5 \alpha$-R activity 
present in oligodendrocytes (Melcangi et al., 1988b, 1993, 1994a) varies across the different phases of myelinization (Melcangi et al., 1988b).

Corticoids also appear able to control the synthesis and expression of specific astrocytic markers. However, the data are difficult to interpret since various types of steroids with different specific activities and with different glucocorticoid versus minerocorticoid ratios have been used. Moreover, the administration schedules and times of observation also have been very variable. For instance, in vivo treatment with dexamethasone, performed in the neonatal rat, significantly diminishes GFAP gene expression (Tsuneishi et al., 1991). Corticosterone administrated in vivo to neonatal or adult rats also inhibits GFAP gene expression and synthesis (Tsuneishi et al., 1991, Laping et al., 1991, 1994; Nichols et al., 1990a,b; O'Callaghan et al., 1989). In line with this observation, adrenalectomy performed in adult rats has been shown to increase GFAP mRNA and protein, an effect which is reversed by corticosterone administration (Laping et al., 1994). However, a different pattern of activity is shown by corticosterone in vitro, since exposure of cultured astrocytes to this steroid induces an increase in GFAP mRNA and protein (Rozovsky et al., 1995). Surprisingly, this effect of corticosterone on GFAP is reversed if astrocytes are cocultured with neurons, a finding which suggests that there is cross-talk between the two types of cells, and provides a possible explanation for the discrepancies between results obtained in vivo and in vitro (Rozovsky et al., 1995). Because of this, a study similar to that previously described for MBP was performed using astrocytic cultures. GFAP mRNA was increased by exposure to corticosterone for 6 and $24 \mathrm{~h}$, while DHC was ineffective. The minerocorticoid DOC was also ineffective, while its $5 \alpha$-reduced derivative, DHDOC, strongly inhibited GFAP gene expression (Melcangi et al., 1997a). The observation that corticosterone increases GFAP gene expression in A1 in cultures is not surprising, since similar data were reported by Rozovsky et al. (1995) using a similar experimental protocol. The present data suggest in addition that this effect is probably not linked to the $5 \alpha$-reduction of the steroid, since the effect of corticosterone is not duplicated by DHC, a steroid that was not included in the study of Rozovsky et al. (1995). It is interesting to note that the stimulatory effect of corticosterone, a steroid with mixed glucominerocorticoid activities, on GFAP expression are not duplicated by the pure minerocorticoid derivative used. This fact suggests that the effect observed may be due to the glucocorticoid rather than minerocorticoid properties of corticosterone. This hypothesis obviously needs confirmation in studies with a "pure"
GR agonist. It is relevant to the present discussion to recall that the synthesis of GFAP may represent an early response of astrocytes and microglia to brain injury and lesioning (Laping et al., 1994). Consequently, one might extrapolate from the present data that stress might influence GFAP synthesis also via the activation of the adrenal cortex.

The present data have shown that at least one $5 \alpha$-reduced metabolite of adrenal steroids (DHDOC) exerts a similar effect on MBP gene expression in oligodendrocytes and GFAP gene expression in astrocytes, with a decrease of their mRNA levels. Even if DHDOC is converted into THDOC, the GABA receptor does not appear to be involved since THDOC, which interacts with the $\mathrm{GABA}_{\mathrm{A}}$ receptor (Rupprecht et al., 1996, 1993), is totally ineffective in regulating either MBP or GFAP gene expression.

\section{GLIAL-NEURONAL INTERACTIONS IN THE CNS}

For many years, glial cells have been considered to represent only mechanical support for neurons. This concept is obviously no longer acceptable. The existence of important functional relationships between specific glial components (oligodendrocytes, astrocytes, etc.) and neurons have become apparent. The interaction of glial cells with neurons plays an important role in neuronal migration, neurite outgrowth, and axonal guidance during neural development (Rakic, 1971; Banker, 1980; Lindsay, 1987; Hatten et al., 1988; Gasser and Hatten, 1990). Moreover, it has recently been demonstrated that glial cells synthesize and possibly release an array of bioactive agents such as neurotransmitters, growth factors, interleukines, prostaglandins, excitatory amino acids, polyamines, and neurosteroids (for review, see LoPachin and Aschner, 1993). It is likely that several of these agents exert definite and specific influences on neuronal activity. On the other hand, glial-neuronal interactions are certainly not one-way, since neurons can interfere with the proliferation and maturation of glial elements. For example, neuronal activity has been shown to up-regulate the expression of GFAP (Steward et al., 1991). Moreover, other parameters of astrocytic function, such as the enzyme glutamine synthetase (Mearow et al., 1990), the formation of gangliosides (Mendez-Otero and Constantine-Paton, 1990), and the assembly of voltage-sensitive calcium channels (Corvalan et al., 1990), are activated only in the presence of neurons. Thus, the concept has emerged that neurons and glia (astrocytes type 1 and 2, oligodendrocytes), in the CNS form a functional unit in which 
each single element exerts effects on the other. As it has been previously mentioned, the enzyme $5 \alpha$-R is present both in neurons (where it shows its higher concentrations) and in the glia (Melcangi et al., 1993, 1994a), while the enzyme $3 \alpha$-HSD is almost exclusively present in A1 (Melcangi et al., 1993, 1994a). The cellular localization of these two enzymes in the brain has prompted us to investigate whether neurons and glial cells interact via humoral messages to control these two enzymes.

Two approaches have been used to examine the interactions between A1 and neurons: (a) a coculture system in which the two types of cells remain physically separated but which allows the free transfer of secretory products from one to the other type of cocultured cells, and (b) the addition of neuron-conditioned medium (CM) to cultures of $\mathrm{A} 1$, and astrocytic CM to cultures of neurons. The data have consistently shown that coculture with neurons or exposure to the neuronal $\mathrm{CM}$ stimulates $5 \alpha-\mathrm{R}$ and $3 \alpha$-HSD activities in A1. In contrast, there was no effect of astrocyte secretory products on the enzymatic activity of neurons (Melcangi et al., 1994b, 1995a). It appears that one or more soluble substance(s) are secreted by neurons which are able to stimulate the two enzymes in A1. Experiments presently are attempting to elucidate the nature of the compound(s) involved. Since the physiological role of the $5 \alpha$-R- $3 \alpha$-HSD system in glial cells is largely unknown, it is difficult to speculate on the biological significance of a neuronal mechanism that stimulates the metabolism of steroid hormones in A1 cells. However, one should recall that the formation of DHT is a mechanism for potentiating androgenic actions, while the subsequent conversion to $3 \alpha$-diol is a mechanism of steroid catabolism, since $3 \alpha$-diol is much less effective than $\mathrm{T}$ as an androgen and does not bind to the androgen receptor (for review, see Celotti et al., 1992; Martini, 1982). Consequently, neuronal influences on A1 cells may increase (by acting on the $5 \alpha-\mathrm{R}$ ), or decrease (by acting on the $3 \alpha$-HSD), the androgenic potential of circulating T. However, the physiological meaning of this phenomenon remains to be established.

The same coculture system and transfer of CM of A1 have been used to analyze the possible effects of astrocytic secretions on a neuronal cell line, the GT1-1 cells, which synthesize and secrete LHRH. This cell line derives from a hypothalamic LHRHproducing tumor, induced by genetically targeted tumorigenesis in a female transgenic mouse. We have found that $\mathrm{CM}$ of $\mathrm{A} 1$ mimics the effect of coculture in that it strongly stimulates the release of LHRH from GT1-1 cells (Melcangi et al., 1995b). TGF $\beta$ appears to be the putative secreted factor that astrocytes release to induce LHRH secretion, since the activity of $\mathrm{CM}$ of A1 is fully antagonized by a TGF $\beta$-neutralizing antibody. Moreover, direct exposure to TGF $\beta 1$, like the addition of $\mathrm{CM}$ of A1, stimulates LHRH release from GT1-1 cells (Melcangi et al., 1995b). In parallel experiments, it was shown that TGF $\beta 1$, as well as CM of A1, also modifies LHRH gene expression in GT1-1 cells (Galbiati et al., 1996). GT1-1 cells also appear to be steroid sensitive since they express receptors for estrogens, androgens, progestins, and corticosteroids (Poletti et al., 1994; Chandran et al., 1994; for review, see Herbison, 1998) and also possess $5 \alpha-\mathrm{R}$ and $3 \alpha$-HSD activities (Poletti et al., 1994; Melcangi et al., 1997b). Consequently, A1 in a coculture system, might alter these enzymatic activities in GT1-1 cells and modify the conversion of two possible substrates for this enzyme. When the conversion of $\mathrm{T}$ and $\mathrm{P}$ was examined, we found that the presence of A1 modifies $5 \alpha-\mathrm{R}$ activity in GT1-1 cells. Surprisingly, the effects observed were different depending on the substrates used. Using $\mathrm{T}$ as the substrate, a significant decrease of the formation of DHT was apparent when GT1-1 cells were cocultured with A1. When $\mathrm{P}$ was used as the substrate, a significant increase in the formation of DHP was observed (Melcangi et al., 1997b). These observations are intriguing since they suggest that the substrate itself may influence $5 \alpha$-R activity. The differential effects on the formation of DHT and DHP cannot be explained on the basis of an effect on either one of the two isoforms of the $5 \alpha-\mathrm{R}$ thus far cloned. In the authors' opinion, these data may be better explained by postulating the existence of a third $5 \alpha-\mathrm{R}$ isoform which has not yet been cloned. Several other observations made recently in this laboratory, both in vitro and in vivo, support such a hypothesis. For example, pluripotential CNS stem cells derived from mice striatum, when induced in culture to differentiate into glial cells, start forming DHT from $\mathrm{T}$ on the 14th day of differentiation, whereas they start forming DHP from $\mathrm{P}$ on the 10th day of differentiation (Melcangi et al., 1996b). The CM of C6 glioma and of 1321N1 human astrocytoma cell lines are unable to modify the formation of DHT from $\mathrm{T}$ in A1, while inducing a statistically significant decrease in the formation of DHP from $\mathrm{P}$ in the same astrocytic cultures (Melcangi et al., 1998b). The exposure of C6 cells to CM of rat fetal neurons stimulates the formation DHT but not DHP (Melcangi et al., 1998b). Furthermore, we recently observed that castration decreases the formation of DHT in the sciatic nerve of adult male rats but leaves unmodified that of DHP (Magnaghi et al., submitted for publication). 


\section{PERIPHERAL NERVOUS SYSTEM}

\section{$5 \alpha-R-3 \alpha-H S D$ Complex}

It has been previously mentioned that in the CNS, $5 \alpha-\mathrm{R}$ is present in elevated concentrations in white matter (Melcangi et al. 1988a, 1989) as well as in purified myelin membranes (Melcangi et al., 1988a,b); central myelin membranes, however, do not seem to possess $3 \alpha$-HSD activity (Melcangi et al., $1988 \mathrm{a}, \mathrm{b})$. To evaluate the possible presence of the $5 \alpha$-R-3 $\alpha$-HSD complex in myelinated nerves of the PNS, the metabolism of T into its $5 \alpha$-reduced metabolites was evaluated in the sciatic nerve of adult male rats, a myelinated peripheral sensorimotor nerve. The study has shown that there is a conspicuous metabolism of $\mathrm{T}$ in sciatic nerve. The formation of DHT was at least equal to that found in central white matter and higher than that found in the cerebral cortex (Melcangi et al., 1990b, 1992). Moreover, in contrast to the low production of $3 \alpha$-diol in the CNS (Melcangi et al., 1988a), $3 \alpha$-diol is produced in amounts similar to those of DHT in the sciatic nerve (Melcangi et al., 1990b, 1992). To the authors' knowledge, until these data were published, no information was available on the uptake and metabolism of testosterone in peripheral nerves, which had never been considered as possible target structures for androgenic steroids and, more generally, for hormonal steroids. On the basis of these preliminary observations, it was suggested that also the PNS might be included among steroid-sensitive target structures. Recent findings that mRNA for $\mathrm{AR}$ is present in male rat sciatic nerve extracts support this assumption (Melcangi et al., 1998a). In this context, it is necessary to underline once more that the $5 \alpha$ - $\mathrm{R}$ also metabolizes $\mathrm{P}$ and corticosteroids (for review, see Celotti et al., 1992). It remains to be ascertained which of these three families of steroids (androgens, progestins, and/or corticosteroids) represents the physiological substrate for the $5 \alpha$-R-3 $\alpha$-HSD complex in sciatic nerve. The observation that $3 \alpha$-diol is formed with considerable yields in sciatic nerve is surprising on the basis of observations previously reported (Melcangi et al., 1990b, 1992) that this metabolite is completely absent in purified CNS myelin. The high peripheral production of $3 \alpha$-diol might be explained by the fact that the peripheral myelin differs metabolically from its central counterpart; this is certainly supported by the finding that the peripheral myelin has a biochemical composition different from that of the brain (see below).

An additional clear-cut difference between central and peripheral myelin was encountered when animals of different age were studied. There was an age- related drop of $5 \alpha-\mathrm{R}$ activity in peripheral nerves, while $5 \alpha$-R was unaffected by age in the CNS, (Melcangi et al., 1990b, 1992).

\section{ROLE OF STEROIDS AND EFFECT OF AGING ON PERIPHERAL MYELIN}

Old and recent morphological observations indicate that in aged mammals, the axons of large myelinated fibers of the PNS undergo atrophy and their myelin sheaths increase in thickness, develop irregularities (Thomas et al., 1980; Grover-Johnson and Spencer, 1981; Johansson et al., 1996), and show the appearance of bubbles (Grover-Johnson and Spencer, 1981; Spencer and Thomas, 1970) and of adaxonal Schwann cell protrusions, a process through which Schwann cells remove debris from the axoplasm (Spencer and Thomas, 1974). Furthermore, the ratio between nodal spacing and fiber diameter increases and signs of Wallerian degeneration may occur (Thomas et al., 1980). In peripheral nerves of aged rats, dogs, cats (Adinolfi et al., 1991; Chase et al., 1992; Morales et al., 1987), and humans (Downie and Newell, 1961; Mayer, 1963), these age-related morphological changes indicate segmental demyelination and are associated with a functional deterioration and a decreased velocity of conduction (Adinolfi et al., 1991; Chase et al., 1992; Morales et al., 1987; Downie and Newell, 1961; Mayer, 1963). Surprisingly, there are no data to show whether aging affects gene expression and synthesis of myelin-related proteins such as the glycoprotein $\mathrm{Po}(\mathrm{Po}), \mathrm{MBP}$, and peripheral myelin protein 22 (PMP22) in peripheral nerve. Po (for review, see Spiryda, 1998) is the most abundant protein of the peripheral myelin (about $50 \%$ of the total) in several animal species including humans (Isaque et al. 1980). This protein is a specific product of Schwann cells (Brockes et al., 1980), and is consequently absent in the CNS (Kitamura et al., 1976). Po is considered an integral membrane protein and may be glycosylated (Kitamura et al., 1976; Everly et al., 1973; Roomi et al., 1978), phosphorylated (Singh and Spritz, 1976; Wiggins and Morell, 1980), sulfated (Matthieu et al., 1975), and acylated (Agrawal et al., 1983; Sakamoto et al., 1986). The protein is thought to play an important physiological role in the maintenance of the multilamellar structure of PNS myelin (D'Urso et al., 1990), serving to link adjacent lamellae via homophyllic binding of Po on extracellular surfaces, and thereby stabilizing the assembly of compact myelin (Lemke, 1986; Snipes and Suter, 1995). MBP, the second most abundant protein in the PNS (Stahl et al., 1990), is localized at the cytoplasm 
apposition of myelin lamellae (the major dense line), and is also believed to be important for myelin compaction at this surface (Campagnoni and Macklin, 1988; Lemke, 1986; Snipes and Suter, 1995). PMP22 represents $2-5 \%$ of the peripheral myelin in rodents and humans (Pareek et al., 1993). The pattern of expression of this protein is synchronous with myelin formation; the protein appears almost exclusively in the compact sheath, where it is involved in regulating myelin stability (Snipes et al., 1992; Kuhn et al., 1993; Zoidl et al., 1995).

Given that little is known about the effects of aging on myelin gene expression in perpheral nerve, we analyzed whether the process of aging might be associated with measurable modifications of Po, MBP, and PMP22 gene expression in the sciatic nerve of the male rat. Because of the presence of PR in Schwann cells (Jung-Testas et al., 1996; Magnaghi et al., 1999), we also analyzed whether physiological progestational agents such as $\mathrm{P}$ and its $5 \alpha$-reduced metabolites could modulate, when given in vivo to aged rats, the levels of Po, MBP, and PMP22 mRNA. Finally, we tested whether these steroids might influence Po and PMP22 gene expression in 3- to 4-month-old adult rats and in Schwann cell cultures obtained from the sciatic nerve of neonatal rats. Because of the presence of AR in the sciatic nerve (Magnaghi et al., 1999), a few experiments were performed using $\mathrm{T}$ and its $5 \alpha$-reduced metabolite, DHT. Using in situ hybridization and/or Northern blot analysis, we found that mRNAs for Po, MBP, and PMP22 were strongly decreased (about $75 \%$ ) in the sciatic nerves of aged (22- to 24-month-old) male rats compared to the sciatic nerve of 3-month-old male rats (Melcangi et al., 1998c, 1999). These observations provide a possible explanation for the several morphological and functional changes seen in peripheral nerves of aged animals (Thomas et al., 1980; Grover-Johnson and Spencer, 1981; Johansson et al., 1986; Spencer and Thomas, 1970; Adinolfi et al., 1991; Chase et al., 1992; Morales et al., 1987; Downie and Newell, 1961; Mayer, 1963).

The subsequent experiment was designed to investigate whether systemic administration of P, DHP, and THP counteracts the drop in mRNA levels of Po, MBP, and PMP22 in aged animals. The results indicate that $\mathrm{P}$ induces in the sciatic nerve of aged rats a slight increase in Po gene expression. DHP, on the other hand, significantly increases the level of Po mRNA, an effect not duplicated by THP (Melcangi et al., 1998c, 1999). Subsequent experiments have indicated that in the sciatic nerve of male rats, not only Po mRNA levels, but also the levels of Po protein decrease with age (Melcangi et al., 1998d); as in the case of Po gene expression, treatment with DHP proved effective in increasing the levels of Po protein in aged animals (Melcangi et al., 1998d). The fact that P and not DHP was very poorly active in inducing an increase of Po gene expression deserves some consideration. Since the $5 \alpha-\mathrm{R}$ activity in the whole sciatic nerve decreases significantly during aging (Melcangi et al., 1990b, 1992), very little DHP could actually be formed from $\mathrm{P}$ in the aged animals. The effect of steroids on Po gene expression seems to be specific for progestins, since androgens, like $\mathrm{T}$ and its $5 \alpha$ reduced metabolite DHT, were ineffective (Melcangi et al., 1998d). Moreover, P, DHP, and THP had no effect on the expression of MBP and PMP22 genes in aged rats (Melcangi et al., 1998c, 1999).

Subsequent experiments were performed to analyze whether P, DHP, and THP affect Po and PMP22 gene expression in normal adult animals (3-4 months old) rather than in old animals. P, DHP, and THP were all able to increase Po mRNA levels above the levels present in untreated normal controls. From a quantitative point of view, DHP appeared to be more effective than the other two steroids (Melcangi et al., 1999). Like with old animals, P and DHP were ineffective in changing PMP22 mRNA levels in the sciatic nerve of adult male rats. Unexpectedly, THP was extremely effective in increasing PMP22 mRNA levels (Melcangi et al., 1999). The discrepancy between THP in adult and aged animals with regard to Po and PMP22 gene expression deserves some discussion. Since THP may act via the GABAergic system, the possibility exists that $\mathrm{GABA}_{\mathrm{A}}$ receptors might be involved in the control of these two proteins in the sciatic nerve. One hypothesis which may easily explain why THP had no effect in old animals is that $\mathrm{GABA}_{\mathrm{A}}$ receptors in the PNS decrease with advancing age. Unfortunately, no data are available to substantiate this hypothesis. However, it is important to remember that a decrease of GABA binding (Dalezios and Matsokis, 1998) and of $\mathrm{GABA}_{\mathrm{A}}$ receptor subunit mRNAs (Gutierrez et al., 1997) has been observed in the CNS of aged animals. Experiments are in progress in our laboratory to ascertain whether the in vivo activity of the $\mathrm{GABA}_{\mathrm{A}}$ receptors declines or disappears with age in the PNS.

The effect of P, DHP, and THP in the control of peripheral myelin gene expression (with particular attention to Po and PMP22) has also been established in in vitro experiments using cultures of rat Schwann cells. Within $2 \mathrm{~h}, \mathrm{P}$ and DHP induced a significant increase of Po gene expression. This effect decreased at later intervals $(6 \mathrm{~h})$. There was no effect on PMP22 gene expression of either steroid. However, THP proved very effective in stimulating both Po and 
PMP22 gene expression in cultured Schwann cells (Melcangi et al., 1998c, 1999). The responses to steroids by cultured Schwann cells appeared to be identical to those observed in vivo in adult animals. It is possible that $\mathrm{P}$, DHP, and THP act via different mechanisms. Because $\mathrm{P}$ and DHP bind to the PR, their effect might be due to the activation of classical progesterone responsive element (PRE) (Rupprecht et al., 1993, 1996). In contrast, THP does not interact with $\mathrm{PR}$, but is a potent agonist for the $\mathrm{GABA}_{\mathrm{A}}$ receptor (Celotti et al., 1992). Because of this possibility, reverse transcriptase-polymerase chain reaction (RT-PCR) was used to determine whether subunits of the $\mathrm{GABA}_{\mathrm{A}}$ receptor are expressed in the sciatic nerve and in cultured Schwann cells. Primer pairs specific for the rat subunit subtypes $\alpha 1, \alpha 2, \alpha 3$, $\alpha 6, \beta 1, \beta 2, \beta 3, \gamma 1, \gamma 2 \mathrm{~L}$, and $\gamma 2 \mathrm{~S}$ were used. The major bands found in the sciatic nerve of adult male rats were those of $\alpha 2, \alpha 3, \beta 1, \beta 2$, and $\beta 3$. Cultured Schwann cells showed a similar pattern of expression of $\mathrm{GABA}_{\mathrm{A}}$ subunit mRNAs, although with different band intensities. The RT-PCR products were confirmed by sequencing, and the results indicated 100\% identity with mRNA sequences of $\alpha 3$ (a.n. X51991), $\beta 1$ (a.n. X15466), $\beta 2$ (a.n. X15467), and $\beta 3$ (a.n. U14420), and 97\% homology for $\alpha 2$ (a.n. L08491) (Melcangi et al., 1999). The presence of $\mathrm{GABA}_{\mathrm{A}}$ receptor subunits in the sciatic nerve and cultured Schwann cells raises the possibility that the effects of THP on Po and PMP22 gene expression are due to an effect of the steroid on this neurotransmitter receptor system. The situation, however, may be different for these two proteins. Keeping in mind that both DHP and THP increase Po gene expression, whereas only THP increases PMP22 gene expression, and that the sciatic nerve and Schwann cells possess the enzyme $3 \alpha$-HSD, which is bidirectional, we propose that THP might be retroconverted to DHP and bind to the PR. An effect of P, DHP, and THP through the PR is certainly supported by the results of a computer analysis we recently performed which identified more than one putative progesterone responsive elements in the Po promoter region (Magnaghi et al., 1999). In the control of Po gene expression, the classical mode of action, by interaction to PR, may prevail over the GABAergic mechanism. A similar explanation cannot apply to the effect of THP on PMP22 gene expression, since DHP was ineffective on the expression of this gene (Melcangi et al., 1999). Consequently, a GABAergic mechanism may be the mode of action for THP on PMP22 gene expression. However, Désarnaud et al. (1998), using a different experimental setup (Schwann cells transiently transfected with a reporter construct), found that $P$ stimulates the expres- sion of the PMP22 gene acting on promoter 1, but not promoter 2. Reasons for this discrepancy may reside in the differences between the two experimental models used.

In conclusion, the present data show that the gene expression of two important proteins of the peripheral myelin (PMP22 and Po) can be influenced by progesterone derivatives. The hypothesis has been put forward that part of the hormonal effects might occur not through the classical PR, but rather via an interaction with the $\mathrm{GABA}_{\mathrm{A}}$ receptor. In particular, hormonal regulation of Po gene expression might be via the PR, whereas expression of PMP22 gene might be controlled by progestagen activity via an interaction with the GABAergic system. Use of molecules that interact with either the PR or the $\mathrm{GABA}_{\mathrm{A}}$ receptor may serve as new therapeutic approaches in demyelinating diseases that are characterized by alterations in Po or PMP22 synthesis, respectively. Experiments are currently in progress to confirm this hypothesis.

The work described here was supported by CNR through Projects AGING (Contract No. 95.01020.PF40) and FATMA (Contract No. 95.00868.PF41). The financial support of Telethon Italy (Grant E.765) is gratefully acknowledged.

\section{REFERENCES}

Adinolfi AM, Yamury J, Morales FR, Chase MH. 1991. Segmental demyelination in peripheral nerves of old cats. Neurobiol Aging 12:175-179.

Agrawal HC, Schmidt RE, Agrawal D. 1983. In vivo incorporation of $\left[{ }^{3} \mathrm{H}\right]$ palmitic acid into Po protein, the major intrinsic protein of rat sciatic nerve myelin. J Biol Chem 258:6556-6560.

Andersson S, Bishop RW, Russell DW. 1989. Expression and regulation of steroid $5 \alpha$-reductase, an enzyme essential for male sexual differentiation. J Biol Chem 264: 16249-16255.

Andersson S, Berman DM, Jenkins EP, Russell DW. 1991. Deletion of steroid $5 \alpha$-reductase 2 gene in male pseudohermaphroditism. Nature 354:159-161.

Banker GA. 1980. Trophic interactions between astroglial cells and hippocampal neurons in culture. Science 209: 809-810.

Brockes JP, Raff MC, Nishiguchi DJ, Winter J. 1980. Studies on cultured rat Schwann cells: assay for peripheral myelin proteins. J Neurocytol 9:67-77.

Campagnoni AT, Macklin WB. 1988. Cellular and molecular aspect of myelin protein gene expression. Mol Neurobiol 2:41-89.

Celotti F, Melcangi RC, Martini L. 1992. The $5 \alpha$-reductase in the brain: molecular aspects and relation to brain function. Front Neuroendocrinol 13:163-215. 
Chandran UR, Attardi B, Friedman R, Dong K-W, Roberts JL, DeFranco DB. 1994. Glucocorticoid receptor-mediated repression of gonadotropin-releasing hormone promoter activity in GT1 hypothalamic cell lines. Endocrinology 134:1467-1474.

Chase MH, Engelhardt JK, Adinolfi AM, Chirwa SS. 1992. Age-dependent changes in cat masseter nerve: an electrophysiological and morphological study. Brain Res 586:279-288.

Chowen JA, Busiguina S, Garcia-Segura LM. 1995. Sexual dimorphism and sex steroid modulation of glial fibrillary acidic protein (GFAP) mRNA and immunoreactive levels in the rat hypothalamus, Neuroscience 69:519-532.

Corvalan V, Cole R, de Vellis J, Hagiwara S. 1990. Neuronal modulation of calcium channel activity in cultured rat astrocytes. Proc Natl Acad Sci USA 87:4345-4348.

Dalezios Y, Matsokis N. 1998. Brain benzodiazepine binding in aged rats. Neurochem Int 32:213-217.

Day JR, Laping NJ, McNeill TH, Schreiber SS, Pasinetti G, Finch CE. 1990. Castration enhances expression of glial fibrillary acidic protein and sulfated glycoprotein- 2 in the intact and lesion-altered hippocampus of the adult male rat. Mol Endocrinol 4:1995-2002.

Day JR, Laping NJ, Lampert-Etchells M, Brown SA, O'Callaghan JP, McNeill TH, Finch CE. 1993. Gonadal steroids regulate the expression of glial fibrillary acidic protein in the adult male rat hippocampus. Neuroscience 55:435-443.

Degtiar VG, Loseva B, Isatchenkov P. 1981. In vitro metabolism of androgens in hypothalamus and pituitary from infantile and adolescent rats of both sexes. Endocrinol Exp 15:181-190.

Désarnaud F, Do Thi AN, Brown AM, Lemke G, Suter U, Baulieu E-E, Schumacher M. 1998. Progesterone stimulates the activity of the promoters of peripheral myelin protein-22 and protein zero genes in Schwann cells. J Neurochem 71:1765-1768.

Downie AW, Newell DJ. 1961. Sensory nerve conduction in patients with diabetes mellitus and controls. Neurology 11:876-882.

D'Urso D, Brophy PJ, Staugaitus SM, Gillespie CS, Frey AB, Stempak JG, Colman DR. 1990. Protein zero of peripheral nerve myelin: biosynthesis, membrane insertion, and evidence for homotypic interaction. Neuron 4:449-460.

Everly JL, Brady RO, Quarles RH. 1973. Evidence that the major protein in rat sciatic nerve myelin is a glycoprotein. J Neurochem 21:329-334.

Galbiati M, Zanisi M, Messi E, Cavarretta I, Martini L, Melcangi RC. 1996. Transforming growth factor- $\beta$ and astrocytic conditioned medium influence luteinizing hormone-releasing hormone gene expression in the hypothalamic cell line GT1. Endocrinology 137:5605-5609.

Garcia-Estrada J, Del Rio JA, Luquin S, Soriano E, GarciaSegura LM. 1993. Gonadal hormones down-regulate reactive gliosis and astrocyte proliferation after a penetrating brain injury. Brain Res 628:271-278.

Garcia-Segura LM, Chowen JA, Duenas M, Torres-Aleman
I, Naftolin F. 1994a. Gonadal steroids as promoters of neuro-glial plasticity. Psychoneuroendocrinology 19: 445-453.

Garcia-Segura LM, Luquin S, Parducz A, Naftolin F. 1994b. Gonadal hormone regulation of glial fibrillary acidic protein immunoreactivity and glial ultrastructure in the rat neuroendocrine hypothalamus. Glia 10:59-69.

Garcia-Segura LM, Chowen JA, Naftolin F. 1996. Endocrine glia: roles of glial cells in the brain actions of steroid and thyroid hormone and in the regulation of hormone secretion. Front Neuroendocrinol 17:180-211.

Garcia-Segura LM, Wozniak A, Azcoitia I, Rodriguez JR, Hutchison RE, Hutchison JB. 1999. Aromatase expression by astrocytes after brain injury: implications for local estrogen formation in brain repair. Neuroscience 89:567-578.

Gasser UE, Hatten ME. 1990. Neuron-glia interactions of rat hippocampal cells in vitro: glial-guided neuronal migration and neuronal regulation of glial differentiation. J Neurosci 10:1276-1285.

Grover-Johnson N, Spencer PS. 1981. Peripheral nerve abnormalities in aging rats. J Neurophatol Exp Neurol 40: $155-165$.

Gutierrez A, Khan ZU, Miralles CP, Mehta AK, Ruano D, Araujo F, Vitorica J, De Blas AL. 1997. GABA A receptor subunit expression changes in the rat cerebellum and cerebral cortex during aging. Mol Brain Res 45:59-70.

Hatten ME, Lynch M, Rydel RE, Sanchez J, Joseph-Silverstein J, Moscatelli D, Rifkin DB. 1988. In vitro neurite extension by granule neurons is dependent upon astroglial-derived fibroblast growth factor. Dev Biol 125:280289.

Herbison AE. 1998. Multimodal influence of estrogen upon gonadotropin-releasing hormone neurons. Endocr Rev 19:302-330.

Ishaque A, Roomi MW, Szymanska I, Kowalski S, Eylar EH. 1980. The Po glycoprotein of peripheral nerve myelin. Can J Biochem 58:913-921.

Johansson CS, Stenstrom M, Hildebrand C. 1996. Target influence on aging of myelinated sensory nerve fibres. Neurobiol Aging 17:61-66.

Jung-Testas I, Renoir JM, Bugnard H, Greene GL, Baulieu EE. 1992. Demonstration of steroid receptors and steroid action in primary cultures of rat glial cells. J Steroid Biochem Mol Biol 41:815-821.

Jung-Testas I, Schumacher M, Robel P, Baulieu EE. 1994. Actions of steroid hormones and growth factors on glial cells of the central and peripheral nervous system. J Steroid Biochem Mol Biol 48:145-154.

Jung-Testas I, Schumacher M, Robel P, Baulieu E-E. 1996. Demonstration of progesterone receptors in rat Schwann cells. J Steroid Biochem Mol Biol 58:77-82.

Kitamura K, Suzuki M, Uyemura K. 1976. Purification and partial characterization of two glycoproteins in bovine peripheral nerve myelin membrane. Biochim Biophys Acta 455:806-816.

Koenig HL, Schumacher M, Ferzaz B, Do Thi AN, Ressouches A, Guennoun R, Jung-Testas I, Robel P, Akwa 
Y, Baulieu E-E. 1995. Progesterone synthesis and myelin formation by Schwann cells. Science 268:1500-1503.

Krieger NR, Scott RG, Jurman ME. 1983. Testosterone $5 \alpha$-reductase in rat brain. J Neurochem 40:1460-1464.

Kuhn G, Lie A, Wilms S, Muller HW. 1993. Coexpression of PMP22 gene with MBP and Po during de novo myelination and nerve repair. Glia 8:256-264.

Labrie F, Sugimoto Y, Luu-The V, Simard J, Lachance Y, Bachvarov D, Leblanc G, Durocher F, Paquet N. 1992. Structure of human type $25 \alpha$-reductase gene. Endocrinology 131:1571-1573.

Langub MC, Watson RE Jr. 1992. Estrogen receptor-immunoreactive glia, endothelia, and ependyma in guinea pig preoptic area and median eminence: electron microscopy. Endocrinology 130:364-372.

Laping NJ, Nichols NR, Day JR, Finch CE. 1991. Corticosterone differentially regulates the bilateral response of astrocyte mRNA in the hippocampus to entorhinal cortex lesions in male rats. Mol Brain Res 10:291-297.

Laping NJ, Teter B, Nichols NR, Rozovsky I, Finch CE. 1994. Glial fibrillary acidic protein: regulation by hormones, cytokines, and growth factors. Brain Pathol 1:259-275.

Lee H, Davies IJ, Ryan KJ. 1979. Progesterone receptor in the hypothalamic cytosol of female rats, Endocrinology 104:791-800.

Lemke G. 1986. Molecular biology of the major myelin genes. Trends Neurosci 9:266-270.

Levy MA, Brandt M, Sheedy KM, Holt DA, Heaslip JI, Trill JJ, Ryan PJ, Morris RA, Garrison LM, Bergsma DJ. 1995. Cloning, expression and functional characterization of type 1 and type 2 steroid $5 \alpha$-reductases from Cynomolgus monkey: comparison with human and rat isoenzymes. J Steroid Biochem Mol Biol 52:307-319.

Lindsay RM. 1987. Adult rat brain astrocytes support survival of both NGF-dependent and NGF-insensitive neurons. Nature 282:80-82.

LoPachin RM Jr, Aschner M. 1993. Glial-neuronal interactions: relevance to neurotoxic mechanisms. Toxicol Appl Pharmacol 118:141-158.

Luquin S, Naftolin F, Garcia-Segura LM. 1993. Natural fluctuation and gonadal hormone regulation of astrocyte immunoreactivity in dentate gyrus. J Neurobiol 24:913924.

MacLusky NJ, Clark CR, Shanabrough M, Naftolin F. 1987. Metabolism and binding of androgen in the spinal cord of the rat. Brain Res 422:83-91.

Magnaghi V, Cavarretta I, Zucchi I, Susani L, Rupprecht R, Hermann B, Martini L, Melcangi RC. 1999. Po gene expression is modulated by androgens in the sciatic nerve of adult male rats. Mol Brain Res 70:36-44.

Majewska MD, Harrison NL, Schwartz RD, Barker JL, Paul SM. 1986. Steroid hormone metabolites are barbituratelike modulators of the GABA receptor. Science 232: 1004-1007.

Martini L. 1982. The $5 \alpha$-reduction of testosterone in the neuroendocrine structures: biochemical and physiological implications. Endocr Rev 3:1-25.
Massa R, Justo S, Martini L. 1975. Conversion of testosterone into $5 \alpha$-reduced metabolites in the anterior pituitary and in the brain of maturing rats. J Steroid Biochem 6:567-571.

Matthieu J-M, Everly JL, Brady RO, Quarles RH. 1975. $\left[{ }^{35} \mathrm{~S}\right]$ Sulfate incorporation into myelin glycoproteins. II. Peripheral nervous system. Biochim Biophys Acta 392: 167-174.

Mayer RF. 1963. Nerve conduction studies in man. Neurology 13:1021-1030.

McEwen BS. 1991. Steroid homones are multifactorial messengers to the brain. Trends Endocrinol Metab 2:62-67.

McEwen BS. 1994. Steroid hormone action in the brain: when is the genome involved? Horm Behav 28:396-405.

McQueen JK, Wright AK, Arbuthnott GW, Fink G. 1990. Glial fibrillary acidic protein (GFAP)-immunoreactive astrocytes are increased in the hypothalamus of androgen-insensitive testicular feminized (Tfm) mice. Neurosci Lett 118:77-81.

McQueen JK. 1994. Glial cells and neuroendocrine function. J Endocrinol 143:411-415.

Mearow KM, Mill JF, Freese E. 1990. Neuron-glial interactions involved in the regulation of glutamine synthetase. Glia 3:385-392.

Melcangi RC, Celotti F, Ballabio M, Poletti A, Castano P, Martini L. 1988a. Testosterone $5 \alpha$-reductase activity in the rat brain is highly concentrated in white matter structures and in purified myelin sheaths of axon. J Steroid Biochem 31:173-179.

Melcangi RC, Celotti F, Ballabio M, Castano P, Poletti A, Milani S, Martini L. 1988b. Ontogenetic development of the $5 \alpha$-reductase in the rat brain: cerebral cortex, hypothalamus, purified myelin and isolated oligodendrocytes. Dev Brain Res 44:181-188.

Melcangi RC, Celotti F, Ballabio M, Carnaghi R, Poletti A, Martini L. 1989. Effect of postnatal starvation on the $5 \alpha$-reductase activity of the brain and of isolated myelin membranes. Exp Clin Endocrinol 94:253-261.

Melcangi RC, Celotti F, Ballabio M, Castano P, Massarelli R, Poletti A, Martini L. 1990a. 5 $\alpha$-Reductase activity in isolated and cultured neuronal and glial cells of the rat. Brain Res 516:229-236.

Melcangi RC, Celotti F, Ballabio M, Poletti A, Martini L. 1990b. Testosterone metabolism in peripheral nerves: presence of the $5 \alpha$-reductase- $3 \alpha$-hydroxysteroid-dehydrogenase enzymatic system in the sciatic nerve of adult and aged rats. J Steroid Biochem 35:145-148.

Melcangi RC, Celotti F, Castano P, Martini L. 1992. Is the $5 \alpha$-reductase- $3 \alpha$-hydroxysteroid dehydrogenase complex associated with the myelin in the peripheral nervous system of young and old male rats? Endocr Reg 26;119125.

Melcangi RC, Celotti F, Castano P, Martini L. 1993. Differential localization of the $5 \alpha$-reductase and the $3 \alpha$ hydroxysteroid dehydrogenase in neuronal and glial cultures. Endocrinology 132:1252-1259

Melcangi RC, Celotti F, Martini L. 1994a. Progesterone $5 \alpha$-reduction in neuronal and in different types of glial 
cell cultures: type 1 and 2 astrocytes and oligodendrocytes. Brain Res 639:202-206.

Melcangi RC, Celotti F, Martini L. 1994b. Neurons influence the metabolism of testosterone in cultured astrocytes via humoral signals. Endocrine 2:709-713.

Melcangi RC, Ballabio M, Magnaghi V, Celotti F. 1995a. Metabolism of steroids in pure cultures of neurons and glial cells: role of intracellular signalling. J Steroid Biochem Mol Biol 53:331-336.

Melcangi RC, Galbiati M, Messi E, Piva F, Martini L, Motta M. 1995b. Type 1 astrocytes influence luteinizing hormone-releasing hormone release from the hypothalamic cell line GT1-1: is transforming growth factor- $\beta$ the principle involved? Endocrinology 136:679-686.

Melcangi RC, Riva MA, Fumagalli F, Magnaghi V, Racagni G, Martini L. 1996a. Effect of progesterone, testosterone and their $5 \alpha$-reduced metabolites on GFAP gene expression in type 1 astrocytes. Brain Res 711:1015 .

Melcangi RC, Froelichsthal P, Martini L, Vescovi AL. 1996b. Steroid metabolizing enzymes in pluripotential progenitor central nervous system cells: effect of differentiation and maturation. Neuroscience 72:467-475.

Melcangi RC, Magnaghi V, Cavarretta I, Riva MA, Martini L. 1997a. Corticosteroid effects on gene expression of myelin basic protein in oligodendrocytes and of glial fibrillary acidic protein in type 1 astrocytes. J Neuroendocrinol 9:729-733.

Melcangi RC, Galbiati M, Messi E, Magnaghi V, Cavarretta I, Riva MA, Zanisi M. 1997b. Astrocyte-neuron interactions in vitro: role of growth factors and steroids on LHRH dynamics. Brain Res Bull 44:465-469.

Melcangi RC, Cavarretta I, Magnaghi V, Ballabio M, Martini L. 1998a. Androgen control of Po gene expression in the sciatic nerve of the male rat. Soc Neurosci Abstr P-712.6:1799.

Melcangi RC, Cavarretta I, Magnaghi V, Ballabio M, Martini L, Motta M. 1998b. Crosstalk between normal and tumoral brain cells. Endocrine 8:65-71.

Melcangi RC, Magnaghi V, Cavarretta I, Martini L, Piva F. 1998c. Age-induced decrease of glycoprotein Po and myelin basic protein gene expression in the rat sciatic nerve: repair by steroid derivatives. Neuroscience 85 : 569-578.

Melcangi RC, Magnaghi V, Cavarretta I, Riva MA, Piva F, Martini L. 1998d. Effects of steroid hormones on gene expression of glial markers in the central and peripheral nervous system: variations induced by aging. Exp Gerontol 33:827-836.

Melcangi RC, Magnaghi V, Cavarretta I, Zucchi I, Bovolin P, D’Urso D, Martini L. 1999. Progesterone derivatives are able to influence PMP22 and Po gene expression: possible mechanisms of action. J Neurosci Res 56:349357.

Mendez-Otero R, Constantine-Paton M. 1990. Granule cell induction of 9-O-acetyl gangliosides on cerebellar glia in micro-cultures. Dev Biol 138:400-409.

Meyer JS, Fairman KR. 1985. Early adrenalectomy in- creases myelin content of the rat brain. Dev Brain Res 17:1-9.

Morales JFR, Boxer PA, Fung SJ, Chase MH. 1987. Basic electrophysiological properties of spinal cord motoneurons during old age in the cat. J Neurophysiol 58:180194.

Motta M, Zoppi S, Brodie AM, Martini L. 1986. Effect of 1,4,6-androstatriene-3,17-dione (ATD),4-hydroxy-4-androstene-3,17-dione (4-OH-A) and 4-acetoxy-4-androstene-3,17-dione (4-Ac-A) on the $5 \alpha$-reduction of androgens in the rat prostate. J Steroid Biochem 25:593-600.

Negri-Cesi P, Melcangi RC, Celotti F, Martini L. 1992. Aromatase activity in cultured brain cells: difference between neurons and glia. Brain Res 589:327-332.

Nichols NR, Osterburg HH, Masters JN, Millar SL, Finch CE. 1990a. Messenger RNA for glial fibrillary acidic protein is decreased in rat brain following acute and chronic corticosterone treatment. Mol Brain Res 7:1-7.

Nichols NR, Masters JN, Finch CE. 1990b. Changes in gene expression in hippocampus in response to glucocorticoids and stress. Brain Res Bull 24:659-662.

Normington K, Russell DW. 1992. Tissue distribution and kinetic characteristics of rat steroid $5 \alpha$-reductase isozymes: evidence for distinct physiological functions. J Biol Chem 267:19548-19554.

Norton WT, Poduslo SE. 1973. Myelination in the rat brain: changes in myelin composition during brain maturation. J Neurochem 21:759-773.

O'Callaghan JP, Brinton RE, McEwen BS. 1989. Glucocorticoids regulate the concentration of glial fibrillary acidic protein throughout the brain. Brain Res 494:159-161.

Pareek S, Suter U, Snipes GJ, Welcher AA, Shooter EM, Murphy RA. 1993. Detection and processing of peripheral myelin protein PMP22 in cultured Schwann cells. J Biol Chem 268:10372-10379.

Paul SM, Purdy RH. 1992. Neuroactive steroids. FASEB J 6:2311-2322.

Poletti A, Melcangi RC, Negri-Cesi P, Maggi R, Martini L. 1994. Steroid binding and metabolism in the luteinizing hormone-releasing hormone-producing neuronal cell line GT1-1. Endocrinology 135:2623-2628.

Preston SL, McMorris FA. 1984. Adrenalectomy of rats results in hypomyelination of the central nervous system. J Neurochem 42:262-267.

Puia G, Santi M, Vicini S, Pritchett DB, Purdy RH, Paul SM, Seeburg PH, Costa E. 1990. Neurosteroids act on recombinant human $\mathrm{GABA}_{\mathrm{A}}$ receptors, Neuron 4:759765.

Rakic P. 1971. Neuron-glia relationship during granule cell migration in developing cerebellar cortex: a Golgi and electron microscopic study in Macacus rhesus. J Comp Neurol 141:282-312.

Roomi MW, Ishaque A, Khann NR, Eylar EH. 1978. The Po protein: the major glycoprotein of peripheral nerve myelin. Biochim Biophys Acta 536:112-121.

Rozovsky I, Laping NJ, Krohn K, Teter B, O'Callaghan JP, Finch CE. 1995. Transcriptional regulation of glial fibrillary acidic protein by corticosterone in rat astrocytes in 
vitro is influenced by the duration of time in culture and by astrocyte-neuron interactions. Endocrinology 136:2066-2073.

Rupprecht R, Reul JMHM, Trapp T, van Steensel B, Wetzel C, Damm K, Zieglgansberger W, Holsboer F. 1993. Progesterone receptor-mediated effects of neuroactive steroids. Neuron 11:523-530.

Rupprecht R, Hauser CAE, Trapp T, Holsboer F. 1996. Neurosteroids: molecular mechanisms of action and psychopharmacological significance. J Steroid. Biochem Mol Biol 56:163-168.

Russell DW, Wilson JD. 1994. Steroid $5 \alpha$-reductase: two genes/two enzymes. Annu Rev Biochem 63:25-61.

Sakamoto Y, Kitamura K, Yoshimura K, Nishijima T, Uyemura K. 1986. Fatty acid-linked peptides from bovine Po protein in peripheral nerve myelin. Biomed Res 7:261-266.

Schenborn ET, Karavolas HJ. 1983. Hypothalamic progestin receptors: evidence for two classes of high affinity binding sites. Endocrinology 112:121-128.

Sekihara H, Yazaki Y. 1993. 5 $\alpha$-Dihydro-11-deoxycorticosterone as a mineralocorticoid agonist and antagonist: evidence for a weak mineralocorticoid as an antagonist of potent mineralocorticoids. J Steroid Biochem Mol Biol 45:235-238.

Singh H, Spritz N. 1976. Protein kinase associated with peripheral nerve myelin. 1. Phosphorylation of endogenous myelin proteins and exogenous substrates. Biochim Biophys Acta 448:325-337.

Snipes CA, Shore LS. 1982. Metabolism of testosterone in vitro by hypothalamus and other areas of rat brain. Andrologia 14:81-85.

Snipes GJ, Suter U, Welcher AA, Shooter EM. 1992. Characterization of a novel peripheral nervous system myelin protein (PMP22/SR13). J Cell Biol 117:225-238.

Snipes GJ, Suter U. 1995. Molecular anatomy and genetics of myelin proteins in the peripheral nervous system. J Anat 186:483-494.

Spencer PS, Thomas PK. 1970. The examination of isolated nerve fibres by light and electron microscopy with observations on demyelination proximal to neuromas. Acta Neuropathol (Berlin) 16:177-186.
Spencer PS, Thomas PK. 1974. Ultrastructural studies with the dying back process.II. The sequestration and removal by Schwann cells and oligodendrocytes of organelles from normal and diseased axons. J Neurocytol 3:763783.

Spiryda LB. 1998. Myelin protein zero and membrane adhesion. J Neurosci Res 54:137-146.

Stahl N, Harry J, Popko B. 1990. Quantitative analysis of myelin protein gene expression during development in the rat sciatic nerve. Mol Brain Res 8:209-212.

Steward O, Torre ER, Tomasulo R, Lothman E. 1991. Neuronal activity up-regulates astroglial gene expression. Proc Natl Acad Sci USA 88:6819-6823.

Thigpen AE, Russell DW. 1992. Four-amino acid segment in steroid $5 \alpha$-reductase 1 confers sensitivity to finasteride, a competitive inhibitor. J Biol Chem 267:8577-8583.

Thomas PK, King RHM, Sharma AK. 1980. Changes with age in the peripheral nerves of the rat. Acta Neuropathol (Berlin) 52:417-428.

Tsuneishi S, Takada S, Motoike T, Ohashi T, Sano K, Nakamura H. 1991. Effects of dexamethasone on the expression of myelin basic protein, proteolipid protein, and glial fibrillary acidic protein genes in developing rat brain. Dev Brain Res 61:117-123.

Vielkind U, Walencewicz A, Levine JM, Bohn MC. 1990. Type II glucocorticoid receptors are expressed in oligodendrocytes and astrocytes. J Neurosci Res 27:360-373.

Wiggins RC, Morell P. 1980. Phosphorylation and fucosylation of myelin protein in vitro by sciatic nerve from developing rats. J Neurochem 34:627-634.

Wolff JE, Laterra J, Goldstein GW. 1992. Steroid inhibition of neural microvessel morphogenesis in vitro: receptor mediation and astroglial dependence. J Neurochem 58: 1023-1032.

Zoidl G, Blass-Kampmann S, D’Urso D, Schmalenbach C, Muller HW. 1995. Retroviral-mediated gene transfer of the peripheral myelin protein PMP22 in Schwann cells: modulation of cell growth. EMBO J 14:1122-1128.

Zoppi S, Lechuga M, Motta M. 1992. Selective inhibition of the $5 \alpha$-reductase of the rat epididymis. J Steroid Biochem Mol Biol 42:509-514. 